\title{
Attitudes facing pain and the spirituality of chronic renal patients in hemodialysis
}

\author{
Atitudes frente à dor e à espiritualidade dos pacientes renais crônicos em hemodiálise \\ Izabel Cristina Chavez Gomes ${ }^{1}$, Carlene Souza Silva Manzini ${ }^{1}$, Ana Carolina Ottaviani ${ }^{1}$, Barbara Isabela de Paula Moraes ${ }^{2}$, Rafaela \\ Brochine Lanzotti ${ }^{1}$, Fabiana de Souza Orlandi ${ }^{3}$
}

DOI 10.5935/2595-0118.20180061

\section{ABSTRACT}

BACKGROUND AND OBJECTIVES: Recent studies show that religion and spirituality are important for the dialysis patient since these variables have been shown to influence important aspects of quality of life and to cope with the disease. In addition, spirituality may be effective in coping with chronic kidney disease and relieving symptoms arising from hemodialysis. The objective of this study was to evaluate the attitudes towards the pain in patients with chronic kidney disease on hemodialysis and its relation with spirituality.

METHODS: This is a co-relational and cross-sectional study of 50 patients with chronic kidney disease on hemodialysis. The data were collected through an individual interview, using the sociodemographic characterization questionnaire, Brief Pain Inventory and the Pinto and Pais-Ribeiro Spirituality Scale.

RESULTS: Regarding attitudes facing chronic pain measured by the Brief Pain Inventory, the lowest mean score was in the "Solicitude" domain $(1.48 \pm 1.35)$ and the highest in "Incapacity" (3.05 \pm 1.37$)$. As for spirituality, the mean scores were $3.80 \pm 0.39$ and $3.36 \pm 0.67$ in the beliefs and hope/optimism dimensions, respectively. A positive, moderate-magnitude correlation was observed between the hope/ optimism dimension of the Pinto and Pais-Ribeiro Spirituality Scale and the solicitude domains $(r=0.315, \mathrm{p}=0.026)$ and emotion $(\mathrm{r}=0.299, \mathrm{p}=0.035)$ of the Brief Pain Inventory.

CONCLUSION: The relationship between attitudes facing pain and the level of spirituality of the chronic renal patient was confirmed. Therefore, these aspects should be considered in the care provided to help in coping with the treatment and the disease. Keywords: Chronic renal failure, Hemodialysis, Nursing, Pain, Spirituality.

1. Universidade Federal de São Carlos, Programa de Pós-Graduação em Enfermagem, São Carlos, SP, Brasil.

2. Irmandade da Santa Casa de Dracena. Dracena, SP, Brasil

3. Universidade Federal de São Carlos, São Carlos, SP, Brasil.

Submitted on January 24, 2018

Accepted for publication on July 17, 2018.

Conflict of interests: none - Sponsoring sources: Conselho Nacional de Desenvolvimento Científico e Tecnológico sob o parecer n ${ }^{\circ} 794.523$ e a Fundação de Amparo à Pesquisa do Estado de São Paulo sob o n $2014 / 10759-7$.

Correspondence to:

Rodovia Washington Luís, s/n

13565-905 São Carlos, SP, Brasil.

E-mail: fabi_ferreira@yahoo.com.br

(C) Sociedade Brasileira para o Estudo da Dor
RESUMO

JUSTIFICATIVA E OBJETIVOS: Estudos recentes trazem que a religiáo e a espiritualidade são importantes para o paciente dialítico, já que essas variáveis se mostraram influentes em aspectos importantes da qualidade de vida e enfrentamento da doença. Além disso, a espiritualidade pode ser eficaz no enfrentamento da doença renal crônica e alívio dos sintomas advindos da hemodiálise. O objetivo deste estudo foi avaliar as atitudes frente à dor de pacientes com doença renal crônica em hemodiálise e sua relação com a espiritualidade.

MÉTODOS: Trata-se de um estudo correlacional e transversal, realizado com 50 pacientes com doença renal crônica em hemodiálise. Os dados foram coletados por meio de entrevista individual, utilizando-se o questionário de caracterização sociodemográfica, Inventário de Atitudes Frente à Dor-Breve e a Escala de Espiritualidade de Pinto e Pais-Ribeiro.

RESULTADOS: Em relação às atitudes frente à dor crônica, mensuradas pelo Inventário de Atitudes Frente à Dor-Breve, o escore médio mais baixo foi no domínio "Solicitude" $(1,48 \pm 1,35)$ e o mais elevado em "Incapacidade" $(3,05 \pm 1,37)$. Quanto à

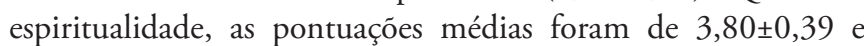
$3,36 \pm 0,67$ nas dimensóes crenças e esperança/otimismo, respectivamente. Observou-se correlação positiva, de moderada magnitude, entre a dimensão esperança/otimismo da Escala de Espiritualidade de Pinto e Pais-Ribeiro e os domínios solicitude $(r=0,315 ; \mathrm{p}=0,026)$ e emoção $(\mathrm{r}=0,299 ; \mathrm{p}=0,035)$ do Inventário de Atitudes Frente à Dor-Breve.

CONCLUSÂO: Confirmou-se a relação entre as atitudes frente à dor e o nível de espiritualidade do paciente renal crônico, logo, tais aspectos deverâo ser considerados na assistência prestada a fim de auxiliar no enfrentamento do tratamento e da doença.

Descritores: Dor, Enfermagem, Espiritualidade, Hemodiálise, Insuficiência renal crônica.

\section{INTRODUCTION}

Chronic kidney disease $(\mathrm{CKD})$ is considered a serious public health problem, with increasing prevalence and incidence ${ }^{1}$. It can be defined as an abnormality in the structure or renal function, present for more than three months, with implications to the health ${ }^{2}$ mainly resulting from systemic arterial hypertension $(\mathrm{SAH})$ or diabetes mellitus (DM) ${ }^{3}$.

The loss of the renal function is slow and gradual, leading the patient with CKD to adaptative processes. In the early stages, it 
is asymptomatic. However, when it reaches $50 \%$ of its normal capacity, symptoms begin to appear, such as mild anemia and nocturia ${ }^{4}$. Facing the diagnosis of an incurable disease, individuals with CKD feel physically and emotionally limited.

The individual under hemodialysis is prone to report pain ${ }^{5}$, a symptom that involves sensitive, emotional, autonomic and behavioral aspects ${ }^{6}$.

The patient with CKD can report different types of pain of varying intensity and location that may be associated with bone diseases, progressive loss of muscle mass, the presence of debilitating chronic diseases such as DM, neurological diseases and vascular obstruction ${ }^{7}$. This situation can interfere with their daily life and compromise their quality of life (QoL).

Among the ways of pain confrontation, spirituality is one of the most important strategies, and religiosity helps in its relief because it increases the number of neurotransmitters involved in this control' ${ }^{5}$. Spirituality is also considered a strong mechanism that helps in stressful moments ${ }^{8,9}$.

Living with the illness and the painful treatment of these patients generate existential conflicts, susceptible to provoke spiritual anguish that can aggravate the physical and emotional symptoms and the capacity to face the disease.-

Recent studies show that religion and spirituality are important for the patient under dialysis since these variables have shown to influence important aspects of the QoL and confrontation of the disease $^{10}$. Thus, considering that spirituality can be effective to cope with CKD and relieve the symptoms of the SAH treatment, this study raised the following guiding question: do CKD patients' attitudes facing the pain have a relationship with their spirituality? From this question, the present research aimed to evaluate the attitudes of $\mathrm{CKD}$ patients under dialysis facing the pain and its relationship with spirituality.

\section{METHODS}

It is a quantitative approach, correlational, cross-section study, conducted in a Substitutive Renal Therapy Unit in the interior of São Paulo, that attended 199 patients in the data collection period (January to April 2016).

Considering the eligibility criteria (18 years of age or older, with a medical diagnosis of CKD in end-stage renal disease, be under hemodialysis and have chronic pain). All the target population was consulted. Of the total of 199 patients attended the service, 50 participated in the study. The sample was of convenience. Of the 149 individuals not included in the study, 10 died, 2 were transferred from the unit, 8 had acute renal failure, 15 were less than 18 years, 64 had no interest in participating in the research, and 50 had acute pain.

The participants who agreed to participate in the study were asked to sign the Free and Informed Consent Form (FICT) in two copies. Then, there was an individual interview in a private room of the service, where the Sociodemographic and Clinical Characterization questionnaire, the Brief Pain Inventory (BPI) and the Pinto and Pais-Ribeiro Spirituality Scale (EEPP-R) were applied. The sociodemographic and clinical characterization questionnaire has been specifically developed for this study with the following sociodemographic variables: gender, age, marital status, education, and religion.

The BPI was elaborated and validated for the Portuguese language in $2006^{11}$ and evaluates the beliefs and how they help to face pain. The short version is composed of 28 items, corresponding to seven belief domains and attitudes facing pain: medical cure (how much the patient believes in medicine to cure his/her pain), control, which refers to how much the patient believes that he can control his/her pain (the personal influence on pain control), solicitude (refers to how much the patient believes that others, especially family members, should be more solicitous when he/she is in pain, solicitude from others when the person is in pain), disability (refers to how much the patient believes he/ she is disabled because of pain), medication (refers to how much the patient believes it is the best treatment for chronic pain), emotions (refers to how much the patient believes that his/her emotions influence the painful experience), and physical damage (refers to how much the patient believes that pain means that he/ she is hurting him/herself and so exercises should be avoided). The score is obtained in a 5-point Likert scale. The points are zero $=$ totally false, 1 = false, 2 = nor true or false, $3=$ almost true, and $4=$ totally true. The score of each scale or domain is calculated by the sum of the answer points of each item, divided by the number of items answered ${ }^{11}$.

The EEPP-R was validated for the Brazilian context in patients with CKD under hemodialysis in $2010^{12}$. It consists of five questions focused on giving meaning/significance to life and the construction of hope and a positive life perspective. The answers are Likert-like, on a scale of four alternatives, from "I disagree" to "totally agree". The factorial analysis resulted in two subscales. One consisting of two items that refer to a vertical dimension of spirituality, called "Beliefs", and another consisting of three items that refer to a horizontal dimension of spirituality, called "Hope/optimism"12. The score of each subscale is obtained by the average of the items, as follows: Beliefs $=($ Questão1 + Questão2) /2; Hope/optimism $=\left(\right.$ Questão3 + Questão4 + Questão5) $/ 3^{12}$. The average cut-off point is 2.5 . The values below this cut-off point correspond to low scores, and the values above correspond to high spirituality scores.

These instruments were applied before the hemodialysis session, or when not feasible, within the first two hours of treatment. Considering the possibility that some of the participants could have visual problems and/or low educational level, the instrument was applied in an individual interview, from January to July 2015. The study complied with the national and international human research ethics standards.

The study was approved by the Research Ethics Committee of the Federal University of São Carlos (opinion number 794.523/2014).

\section{Statistical analysis}

The data was entered in an Excel spreadsheet and transferred to the software Statistical Package for the Social Sciences (SPSS for Windows), version 22.0, for analysis. For the data descriptive analysis, the position measures (average, median and maximum) and the dispersion (standard deviation) were calculated. 
In addition, correlational calculations were performed (Spearman correlation coefficient) and Student $t$ test to check the correlation between pain and spirituality using such scales. In this study, the magnitude of the correlations was classified as weak $(<0.3)$; moderate $(0.3$ to 0.59$)$; strong $(0.6$ to 0.9$)$ and perfect

Table 1. Sociodemographic and clinical characteristics of chronic kidney patients $(n=50)$. São Carlos-SP, 2018

\begin{tabular}{llcc}
\hline Variables & & $\mathrm{n}$ & $\%$ \\
\hline Age group (years) & 18 to 59 & 34 & 68.0 \\
& 60 or older & 16 & 32.0 \\
Gender & Male & 29 & 58.0 \\
& Female & 21 & 42.0 \\
Marital status & With regular partner & 33 & 66.0 \\
\multirow{3}{*}{ Education (years) } & With no regular partner & 17 & 34.0 \\
& Illiterate & 1 & 2.0 \\
& 1 to 4 & 16 & 32.0 \\
& 5 to 9 & 8 & 16.0 \\
& 10 or more & 25 & 50.0 \\
Religion & Catholic & 30 & 60.0 \\
& Evangelic & 14 & 28.0 \\
& Jehovah's Witness & 3 & 6.0 \\
& Spiritist & 2 & 4.0 \\
& Mormon & 1 & 2.0 \\
\hline
\end{tabular}

$(1.0)^{13}$. The significance level adopted for the statistical tests was $\mathrm{p} \leq 0.05$.

\section{RESULTS}

The study included 50 patients characterized by the predominance of males $(58.0 \%)$, most participants aged 18 to 59 years $(68.0 \%)$, the majority had a regular partner (66.0\%). Concerning education, $50 \%$ of the patients reported 10 years or more, and regarding religion, most participants professed Catholicism (60.0\%). Table 1 shows the complete characterization data of patients with CKD.

Regarding attitudes facing pain, evaluated by the BPI, table 2 shows the descriptive analysis obtained in the seven domains: Medical Cure, Control, Solicitude, Disability, Medication, Emotion, and Physical Damage. It was found that the Solicitude domains of the BPI had the lowest average score, and the highest average score was Disability.

Regarding the spirituality level of the CKD patients evaluated by the EEPP-R, table 3 shows that the average score on the beliefs

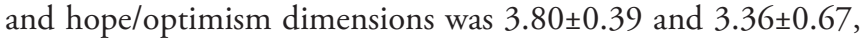
respectively, which means high spirituality scores, taking into account that the cut-off point of that scale is 2.5.

Table 4 shows a significant positive correlation of moderate magnitude between the BPI domains and the hope/optimism subscale of the EEPP-R: Solicitude $(r=0.315$; $\mathrm{p}<0.026)$ and Emotion $(r=0.299 ; \mathrm{p}<0.035)$.

Table 2. Descriptive statistics of scores of the BPI domains. São Carlos-SP, 2018

\begin{tabular}{|c|c|c|c|c|c|}
\hline BPI Domains & Average & Standard deviation & Median & Minimum & Maximum \\
\hline Solicitude & 1.48 & 1.35 & 1.40 & 0.00 & 4.00 \\
\hline Emotion & 1.81 & 1.24 & 1.50 & 0.00 & 4.00 \\
\hline Medical cure & 2.73 & 0.87 & 2.80 & 0.60 & 4.00 \\
\hline Control & 2.77 & 1.15 & 3.00 & 0.00 & 4.00 \\
\hline Physical damage & 2.04 & 1.17 & 2.30 & 0.00 & 4.00 \\
\hline Disability & 3.05 & 1.37 & 4.00 & 0.00 & 4.00 \\
\hline Medication & 2.03 & 0.95 & 2.00 & 0.00 & 4.00 \\
\hline
\end{tabular}

$\mathrm{BPI}=$ Brief Pain Inventory.

Table 3. Descriptive statistics of the spirituality scores of the Pinto e Pais-Ribeiro Scale domains. São Carlos-SP, 2018

\begin{tabular}{lccccc}
\hline EEPP-R & Average & Standard deviation & Median & Minimum & Maximum \\
\hline Beliefs & 3.80 & 0.39 & 4.00 & 2.50 & 4.00 \\
Hope/optimism & 3.36 & 0.67 & 3.50 & 1.67 & 4.00 \\
Total & 3.58 & 0.53 & 3.75 & 2.08 & 4.00 \\
\hline
\end{tabular}

EPPR-R = Pinto and Pais-Ribeiro Spirituality Scale.

Table 4. Spearman's correlation coefficient between the BPI and the EEPP-R domains. São Carlos, 2018

\begin{tabular}{lcccccccc}
\hline EEPP-R & & & \multicolumn{3}{c}{ BPI } & & \\
& & Solicitude & Emotion & Medical cure & Control & Physical damage & Disability & Medication \\
\hline Beliefs & $\mathrm{r}$ & 0.105 & 0.023 & 0.187 & -0.145 & 0.057 & -0.117 & 0.036 \\
& $\mathrm{p}$ & 0.467 & 0.873 & 0.194 & 0.314 & 0.696 & 0.417 & 0.806 \\
Hope/optimism & $\mathrm{r}$ & 0.315 & 0.299 & -0.081 & 0.211 & -0.024 & -0.125 & 0.123 \\
& $\mathrm{p}$ & $0.026^{*}$ & $0.035^{*}$ & 0.575 & 0.142 & 0.870 & 0.387 & 0.396 \\
Total & $\mathrm{r}$ & 0.360 & 0.317 & -0.073 & 0.113 & -0.270 & -0.123 & 0.131 \\
& $\mathrm{p}$ & $0.010^{*}$ & $0.025^{*}$ & 0.613 & 0.436 & 0.850 & 0.394 & 0.363 \\
\hline
\end{tabular}

*with statistical significance.

$\mathrm{BPI}=$ Brief Pain Inventory; EPPR-R = Pinto and Pais-Ribeiro Spirituality Scale. 


\section{DISCUSSION}

Males were prevalent among the participants evaluated, and most of the patients were in the 18 to 59 years age group (68.0\%). In relation to religion, the majority of the participants professed the Catholicism, similar to a pain-oriented study ${ }^{14}$ of patients with CKD where the percentage of the males was $57.5 \%$, and the prevalence was of adults $(51.6 \%)$ and most of the interviewed (61.4\%) reported being Catholics. Other study ${ }^{15}$ showed similarities in these results, where the percentage of the interviewed population that was white was $77.95 \%$ of the total sample. It is believed that this high incidence of CKD is related to the aging process, with the progressive loss of the renal physiologic reserve, and the consequent anatomical and functional changes that occur in the kidneys.

Regarding the marital status, the majority of the respondents had a fixed partner, which can be observed in another study ${ }^{8}$ where $57.7 \%$ stated they were married or had a fixed partner. The result showed that most patients are likely to have family support, which is of great importance since chronic diseases can affect patients` emotional, psychological and socioeconomic status.

Concerning the educational level, there was an average of $3.60 \pm 1.62$ years, ranging from 1 to 9 years, and most of them have completed high school. A study ${ }^{8}$ conducted with patients under hemodialysis obtained data similar to the present investigation, where $17.3 \%$ presented have completed high school. It should be pointed out that the low educational level can influence the social vulnerability and therefore compromise the healthcare of patients with CKD. This information is important for the healthcare professional who assists the patient to have an assertive approach according to the needs and conditions of understanding of each patient.

Regarding the BPI, it was found that the domain with the highest score was Disability, which refers to how much the patient believes that he/she is disabled because of the pain. Three of the domains presented moderate reliability: Medical Cure, referring to how much the patient believes that the medicine can cure his/ her pain. Physical Damage, referring to how much the patient believes that pain means that he/she is hurting him/herself and therefore exercises should be avoided, and Medication, which relates to how much the patient believes that it is the best treatment for chronic pain. The domain with the lowest average score was Solicitude (1.48 \pm 1.35$)$, related to the patient's respect and belief that others, especially family members, should be more solicitous when he/she feels pain.

A study ${ }^{16}$ carried out with 88 CKD patients under hemodialysis in a Nephrology Unit in the Northeast of Rio Grande Do Sul, tried to understand the pain intensity levels of this population using the McGill Questionnaire. The author found that during the session, $75 \%$ of the patients did not have pain, $17 \%$ had mild pain, $4 \%$ moderate, and $3.4 \%$ intense pain. At the end of the dialysis, 58\% were still without pain. However, an approximated percentage of mild or moderate pain (20.5\% and $19.3 \%)$ and intense pain $(2.3 \%)$ showed an increase in the intensity of the pain during the hemodialysis, a result that corroborates the present study.
Regarding the spirituality level of the participants, the average score on the beliefs and hope/optimism dimensions was $3.80 \pm 0.39$ and $3.36 \pm 0.67$, respectively, which means high spirituality scores, taking into account that the cut-off point of that scale is 2.5 .

A study ${ }^{17}$ with the objective of checking the spirituality and hope of patients under cancer treatment, obtained, in the beliefs and hope/optimism dimensions of the EEPP-R the average scores of $2,83 \pm 0.93$ and $2.76 \pm 0.75$, respectively, also indicating a high level of spirituality. This is considering the average score since it varies from 1 to 4 . Therefore, there is evidence that spirituality can be a contributing factor in improving the quality of life of these patients, and the implementation of new public policy must ensure that patients receive spiritual assistance during the treatment.

A study ${ }^{18}$ analyzed the relationship between hope and spirituality in patients under hemodialysis and concluded that there is a positive relationship between the variables, with an average of $3.67 \pm 0.62$ in the beliefs subscale and $3.21 \pm 0.53$ in hope/optimism, values similar to the ones of the present study.

This study can show an indication of positive correlation, of moderate magnitude, with statistical significance between the solicitude and emotion domains of the BPI. Also, there was a negative correlation between the medical cure domain and the total EEPP-R, with statistical significance, of low magnitude, indicating that there is no cure correlation for the CKD patient under hemodialysis when he/she has a high level of spirituality.

A study ${ }^{19}$ conducted with 58 CKD patients under hemodialysis in the Santo Amaro Nephrology Clinic, in Patos, State of Paraíba, showed that religious attitudes help patients in coping with difficult situations, including pain, improving the quality of their life.

No studies were found in the literature dedicated to understanding the association of spirituality with pain in patients with CKD. However, the study ${ }^{20}$ conducted with 10 senior citizens of a physical training program which presented symptoms of intermittent claudication analyzed their perception of pain when walking and how they used spirituality to overcome the painful symptom. The study concluded that faith and spirituality seem to work as an instrument to overcome pain during walking of older people with intermittent claudication.

\section{CONCLUSION}

Based on the proposed objective and the results obtained, it was found that the attitudes facing pain and the spirituality of patients with CKD under dialysis, who participated in this study showed a significant positive correlation between the analyzed dimensions.

There was also a significant positive correlation, showing that spirituality helps in the way patients face the pain caused by the disease and the hemodialysis treatment.

\section{ACKNOWLEDGMENTS}

To the participants who accepted to participate in the study, the Nephrology sector as well as the Nursing and Medical teams. To 
the National Council for Scientific and Technological Development under opinion number 794.523, and to the Research Support Foundation of the State of São Paulo under number 2014/10759-7.

\section{REFERENCES}

1. Sesso RC, Lopes AA, Thomé FS, Lugon JR, Martins CT. [Brazilian Chronic Dialysis Survey 2016]. J Bras Nefrol. 2017;39(3):261-6.

2. Pereira ER, Pereira Ade C, Andrade GB, Naghettini AV, Pinto FK, Batista SR, et al. [Prevalence of chronic renal disease in adults attended by the family health strategy]. J Bras Nefrol. 2016;38(1):22-30. English, Portuguese.

3. Dallacosta FM, Conte AP, Guzzo TL. Detecçâo precoce da insuficiência renal crônica em pacientes hipertensos e diabéticos do município de Joaçaba - SC. Semana Acadêmica e Mostra Científica. 2016;1.

4. Cardoso LB, Sade PM. A enfermeira contra o processo de resiliência do paciente no tratamento hemodialítico. Rev Eletr Faculdade Evangélica do Paraná 2012. Citado em 2017;2(2):1.

5. Rizzardi CD, Teixeira MJ, Siqueira SR. Espiritualidade e religiosidade no enfrentamento da dor. O Mundo da Saúde, 2010;34(4):483-7.

6. Silva JA, Ribeiro-Filho NP. A dor como um problema psicofísico. Rev Dor 2011;12(2):138-51.

7. Silva L, Mendonça AT, Carvalho LA. As características da dor em portadores de insuficiência renal crônica em programa de hemodiálise. Rev Univ Vale Rio Verde. 2013;10(1):590-9.

8. Martínez BB, Custódio RP. Relationship between mental health and spiritual wellbeing among hemodialysis patients: a correlation study. São Paulo Med J. 2014;132(1):23-7.

9. Santos CC, Gomes AM, Oliveira DC, Pontes AP, Santos EI, Costa CP. Diálogos entre espiritualidade e enfermagem: uma revisão integrativa da literatura. Cogitare Enferm. 2013;18(2):372-8
10. Rusa SG, Peripato GI, Pavarini SC, Inouye K, Zazzetta MS, Orlando Fde S. [Quality of life/spirituality, religion and personal beliefs of adult and elderly chronic kidney patients under hemodialysis]. Rev Lat Am Enfermagem. 2014;22(6):911-7. English, Portuguese, Spanish.

11. Pimenta CA, Cruz DA. Crenças em dor crônica: validaçâo do Inventário de Atitudes frente à Dor para a Língua Portuguesa. Rev Esc Enferm USP. 2006;40(3):365-73.

12. Chaves EC, Carvalho EC, Dantas RA, Terra FS, Nogueira DP, Souza L. Validação da escala de espiritualidade de pinto e pais-ribeiro em pacientes com insuficiência renal crônica em hemodiálise. Rev. Enferm UFPE. 2010;4(2):715-21.

13. Levin J, Fox JA. Estatística para ciências humanas. São Paulo: Prentice Hall; 2004

14. Marques VR, Benetti PE, Benetti ER, Rosanelli CL, Colet CF, Stumm EM. Avaliaçāo da intensidade da dor de pacientes renais crônicos em tratamento hemodialítico. Rev Dor. 2016;17(2):96-100.

15. Cesarino CB, Yamamoto K, Cruzeiro NF, Beccaria LM, Oliveira JF, Pinto MH, et al Fatores sociodemográficos associados às complicaçōes dos pacientes renais crônicos durante a hemodiálise. Nursing. 2011;13(153):86-91.

16. Pimenta CA, Kurita GP, Silva EM, Cruz DA. Validade e confiabilidade do Inventário de Atitudes frente à Dor Crônica (IAD-28 itens) em língua portuguesa. Rev Esc Enferm USP. 2009;43(esp):1071-9.

17. Ottaviani AC, Souza ÉN, Drago Nde C, de Mendiondo MS, Pavarini SC, Orland Fde S. [Hope and spirituality among patients with chronic kidney disease undergoing hemodialysis: a correlational study]. Rev Lat Am Enfermagem. 2014;22(2):248-54. English, Portuguese, Spanish.

18. Nunes FA, Nunes SA, Lorena YC. Autoestima, depressão e espiritualidade em pacientes portadores de doença renal crônica em tratamento hemodialítico. Rev Med Res. 2014;16(1):18-26.

19. Almeida KC, Sousa MN, Oliveira T, Bezerra AL, Nunes RM, Medeiro RC. Atitude religiosa de pessoas com doença renal crônica em tratamento hemodialítico. Rev Enf UFPI. 2016;5(2):4-10.

20. Santos AR, Miranda AS, Ritti-Dias RM, Freitas CM. Limitaçôes para caminhar em idosos com claudicação intermitente: a religiosidade como mecanismo de superação da dor. Rev Bras Geriatr Gerontol. 2014;17(2):363-71. 